\title{
Re-evaluating the Relevance of Vegetation Trimlines in the Canadian Arctic as an Indicator of Little Ice Age Paleoenvironments
}

\author{
GABRIEL J. WOLKEN, ${ }^{1,2}$ JOHN H. ENGLAND ${ }^{1}$ and ARTHUR S. DYKE ${ }^{3}$
}

(Received 10 December 2004; accepted in revised form 4 April 2005)

\begin{abstract}
The origin of trimlines associated with the so-called "lichen-free" areas in the Canadian Arctic has been attributed both to perennial snowfield expansion during the Little Ice Age (LIA) and to seasonally persistent snow cover in more recent times. Because of the disparate hypotheses (ecological versus paleoclimatic) regarding the formation of these trimlines, their use as a paleoclimatic indicator has been abandoned for more than two decades. We re-examine this debate and the validity of the opposing hypotheses in the light of new regional mapping of trimlines across the Queen Elizabeth Islands (QEI). The ecological hypothesis-insufficient duration of the growing season resulting from seasonally persistent snow cover-fails to account for the poikilohydric nature of lichens and their ability to endure short growing seasons. It cannot adequately explain the existence of sharp trimlines or account for the occurrence of those trimlines on sparsely vegetated carbonate terrain. Furthermore, trimlines outlining the former extent of thin plateau ice caps are accordant with trimlines associated with former perennial snowfields, indicating that these trimlines record snow and ice expansion during the LIA rather than the seasonal persistence of more recent snow cover. We suggest that these features represent an important LIA climate indicator and should therefore be used for paleoclimatic reconstruction.
\end{abstract}

Key words: trimlines, lichen-free areas, paleoenvironment, Little Ice Age, Arctic Canada, plateau ice caps, climate change, Neoglacial, lichens, seasonal snow cover, glaciers

RÉSUMÉ. L'origine des épaulements propres aux zones dites sans lichen de l'Arctique canadien a été attribuée tant à l'expansion des champs de neige pérenne pendant le petit âge glaciaire qu'à la couverture de neige longévive d'époques plus récentes. Puisqu'il existe des hypothèses disparates (écologiques par opposition à paléoclimatiques) quant à la formation de ces épaulements, on a arrêté de s'en servir à titre d'indicateur paléoclimatique depuis plus d'une vingtaine d'années. Ici, ce débat fait l'objet d'un nouvel examen où l'on se penche sur la validité des hypothèses divergentes à la lumière du nouveau mappage régional des épaulements des îles de la Reine-Élisabeth. L'hypothèse d'ordre écologique - durée insuffisante de la saison de croissance découlant de la couverture de neige longévive en saison - omet de tenir compte de la nature poecilitique du lichen et de son aptitude à endurer de courtes saisons de croissance. Cette hypothèse ne permet pas d'expliquer adéquatement l'existence d'épaulements précis ou de tenir compte de la présence de ces épaulements en terrain carbonaté à végétation éparse. Par ailleurs, les épaulements qui délimitent l'ancienne étendue des minces calottes glaciaires des plateaux correspondent aux épaulements associés aux anciens champs de neige pérenne, ce qui indique que ces épaulements dénotent les expansions de neige et de glace du petit âge glaciaire et non pas de la couverture de neige longévive saisonnière plus récente. On suggère que ces caractéristiques représentent un important indicateur climatique du petit âge glaciaire et par conséquent, qu'on devrait s'en servir à des fins de reconstruction paléoclimatique.

Mots clés: épaulements, zones sans lichen, paléoenvironnement, petit âge glaciaire, Arctique canadien, calottes glaciaires des plateaux, changement climatique, néoglaciaire, lichens, couverture de neige saisonnière, glaciers

Traduit pour la revue Arctic par Nicole Giguère.

\section{INTRODUCTION}

During the Neoglacial (i.e., the last 3000 years), the Canadian High Arctic became markedly colder than it had been during the early to middle Holocene ( 9000 to $3000 \mathrm{BP}$ ) (Bradley, 1990; Kaufman et al., 2004). This period of climatic deterioration led to widespread expansion of the terrestrial snow and ice cover, as well as sea ice and ice shelves, which reached their maximum Neoglacial extent during the Little Ice Age (LIA) ( 1600 to 1900 AD) (Grove, 1988; Koerner and Fisher, 1990). Subsequently, there has been an equally dramatic reduction of this snow and ice cover, occasioned by climate amelioration following the LIA. Neither the cause nor the chronology of the LIA in Arctic Canada is well understood, nor is it clear which factors led to its termination (Overpeck et al.,

\footnotetext{
${ }^{1}$ Department of Earth and Atmospheric Sciences, University of Alberta, Edmonton, Alberta T6G 2E3, Canada

${ }^{2}$ Corresponding author: gwolken@ualberta.ca

${ }^{3}$ Terrain Sciences Division, Geological Survey of Canada, 601 Booth Street, Ottawa, Ontario K1A 0E8, Canada

(C) The Arctic Institute of North America
} 


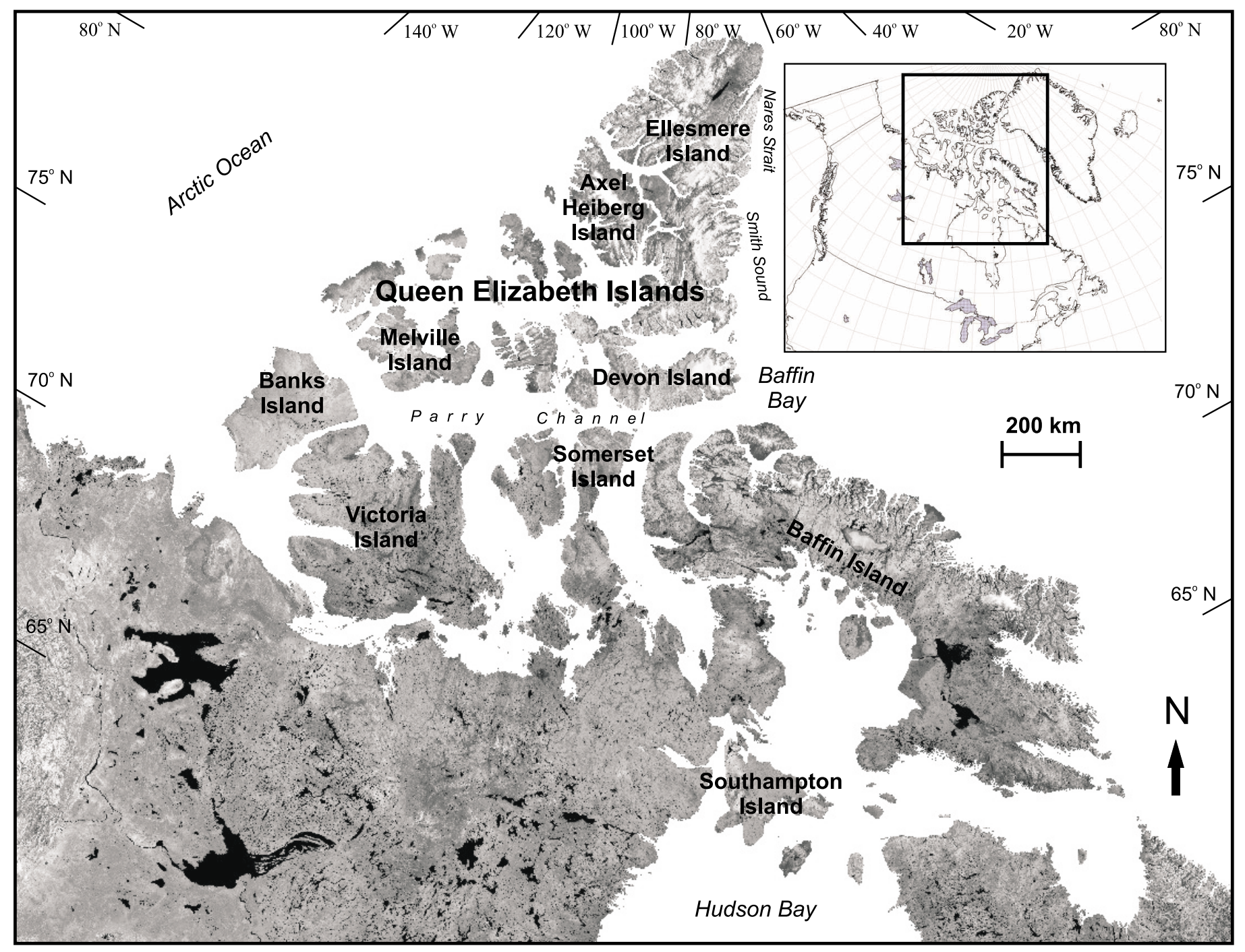

FIG. 1. Map of the Canadian Arctic Archipelago (Radarsat Orthomosaic of Canada courtesy of the Canadian Centre for Remote Sensing).

1997). The instrumental record in the Canadian High Arctic extends back only $\sim 55$ years. A better understanding of the LIA would help to document the nature of climatic variability over longer time scales. This information could then be used to test how well climatic models reproduce past environmental change, thereby improving our ability to forecast future conditions.

Vegetation trimlines surrounding poorly vegetated terrain have commonly been interpreted as evidence of the retreat of LIA snowfields, glaciers, and ice caps (Ives, 1962; Andrews et al., 1975, 1976; Locke and Locke, 1977; Dyke, 1978, 2000a-e, 2001a-e, 2003, 2004; Edlund, 1985; Levesque and Svoboda, 1999; Hooper and Dyke, 2000; Dyke and Hooper, 2000; Dredge, $2004 \mathrm{a}-\mathrm{c}$ ). Consequently, a large reduction in snow and ice cover has been mapped on northern Baffin and Devon islands, where lighter-toned areas with minimal vegetation are evident on aerial photos and satellite images. These areas have been interpreted as areas of incipient plant recolonization following melting of perennial névés. Similar areas occur on more northerly Arctic islands, but they have not been mapped (Fig. 1). Ives
(1962) was the first to recognize expansive but sharply delineated areas with little or no vegetation across the north-central plateau of Baffin Island (Fig. 1). He attributed these to recent melting of former "ice patches and snow-beds" and referred to these zones as "lichen-free" (this term, synonymous with "lichen-kill," implies the destruction of plants as well as lichens). Field observations revealed that the lighter-toned areas on air photos are areas nearly devoid of plants and lichens, whereas the darkertoned areas support mature plant and lichen communities, which in this region typically cover $50-100 \%$ of the ground where the soil is acidic. Building on Ives' observations, Falconer (1966:200) investigated a "sharply defined" trimline encircling a hilltop near the Tiger Ice Cap, Baffin Island, which has now completely melted. The trimline separates "a near continuous growth of large crustose lichens" at the summit from a lichen-free zone below (Falconer, 1966:200). On the basis of estimated lichen growth rates for this area (Andrews and Webber, 1964), Falconer proposed that the hilltop must have remained a nunatak for several hundred years. Falconer also 


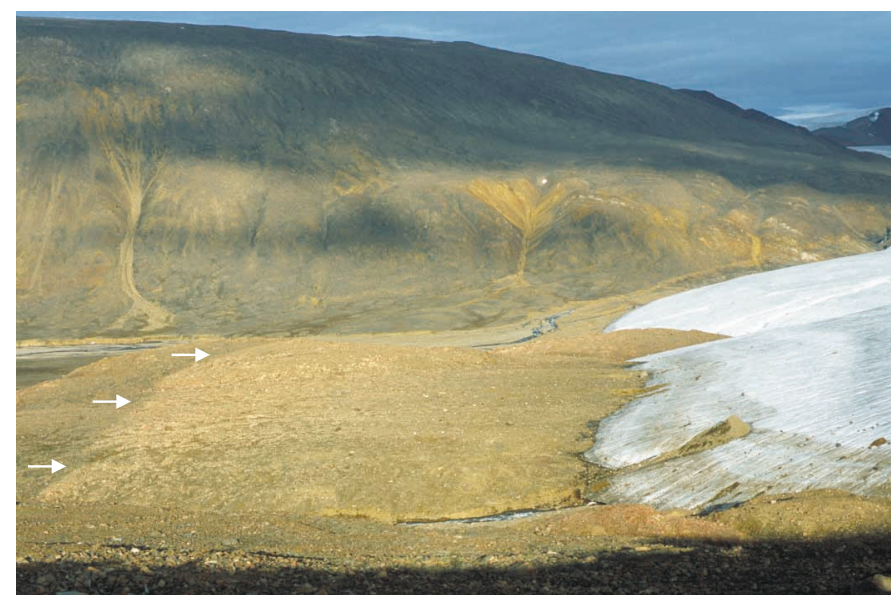

FIG. 2. Twin Glacier, Alexandra Fiord, Ellesmere Island, Canada. The former limit of ice extent is indicated by a lighter-toned zone of reduced vegetation and lichens, delineated distally by an abrupt trimline (white arrows) and proximally by the modern terminus. The distance from the terminus to the trimline is $\sim 140 \mathrm{~m}$.

noted a band of preserved but dead lichen and plant cover around the retreating margin of the Tiger Ice Cap. Inside the trimline, and next to the retreating margin of the ice cap, Falconer collected a clump of preserved, dead moss that was ${ }^{14} \mathrm{C}$ dated to $330 \pm 75$ yr BP. This sample (I-1204) provided a maximum age estimate for the last snow and ice expansion, thus strengthening the interpretation that the "lichen-kill" event occurred during the LIA.

In contrast, Koerner (1980) argued that growing seasons of insufficient duration in more recent times were responsible for the barren sites described by Ives and subsequent workers. This hypothesis departs not only from the traditional interpretation of trimlines on the plateaus of Baffin Island, but also from the generally accepted interpretation of similar trimlines around glaciers in alpine areas around the globe. This debate is central to the interpretation of lichen-free zones. Do prominent trimlines record the former limit of perennial snowfields and ice caps of the LIA (Ives, 1962), or do they simply record the limit of consistently occurring late-lying snowfields that result in an insufficient growing season for lichens, as Koerner (1980) suggests? Although surficial geologists have continued to portray these trimlines in accordance with Ives' hypothesis (references above; Hodgson, 1992), one result of Koerner's rejection of that hypothesis is that these features have not been used for explicit paleoclimatic reconstructions since the early 1980s. Thus, their usage as a measure of climatic change has been abandoned. In a recent review of the postglacial climate history of Arctic Canada, for example, Gajewski and Atkinson (2003:73) stated, “...dating of a more extensive snow cover is not well established, nor is its extent or impacts on arctic ecosystems." In this paper, we revisit the views of both Ives and Koerner in the light of new regional mapping of trimlines across the Queen Elizabeth Islands (QEI) and use these observations to address the origin of the trimlines and their applicability to past climatic change.

\section{OVERVIEW OF TRIMLINES IN ARCTIC CANADA}

\section{Trimline Concept}

Throughout Arctic Canada, and elsewhere in glaciated regions, light-toned, barely vegetated terrains displaying abrupt outer margins extend back to modern glaciers and ice caps (Fig. 2). These margins, referred to as "trimlines," have been universally ascribed to the removal of vegetation, to the freshening of rock surfaces, or to the deposition of new drift, all caused by former glacial cover. Where the former ice cover was neither erosive nor depositional, the result is strictly a vegetation trimline. Such vegetation trimlines will inevitably become indistinct as vegetation slowly becomes re-established in these areas (Benn and Evans, 1998:606). In the Canadian High Arctic, vegetation trimlines are widespread around glaciers and ice caps, but identical features also occur on plateaus that are currently ice-free or nearly so. Vegetation trimlines develop best on crystalline Precambrian terrain that supports welldeveloped vegetation and lichen communities immediately distal to them (Figs. 3 and 4). Although trimlines also exist on carbonate terrain, they are more subtle because of the depauperate vegetation and lichen communities on calcareous soils, which typically support a vegetation cover of $5 \%$ or less (Fig. 5). Nevertheless, trimlines on carbonate substrates are subtly apparent on air photos and high-resolution satellite imagery, where they outline areas of greater albedo. As seen on the ground, these lightertoned areas are surfaces having slightly less surface clast weathering, more frequent flat-lying clasts, and less patterned ground microrelief (Fig. 5). In several places, finely nested arrays of lateral meltwater channels are inset within these light-toned terrains.

\section{Previous Trimline Research in the Canadian Arctic}

The perspectives offered by Ives (1962) and Falconer (1966), proposing a substantial increase in snow and ice in the recent past, regenerated interest in Ives' (1957) earlier hypothesis of instantaneous glacierization. This term implied that the onset of glaciation was occasioned by the lowering of the snowline onto expansive plateaus of northern Canada (Keewatin, Labrador, and Baffin Island). By increasing albedo, this covering resulted in a positive feedback, promoting snowfield expansion. In this view, the expansion of snow and ice during the LIA, as recorded by the distribution of recently exposed trimlines, offered insights regarding processes of ice-sheet inception and growth (Flohn, 1974; Andrews et al., 1975, 1976; Barry, 1975; Ives et al., 1975; Williams, 1975).

Using this trimline model, Andrews et al. $(1975,1976)$ compiled the first reconstruction of LIA perennial snow cover for north-central Baffin Island. This reconstruction was based on the mapping of light-toned areas from air photo and Landsat-1 satellite imagery, combined with fieldwork. Chronological control for trimline age was 


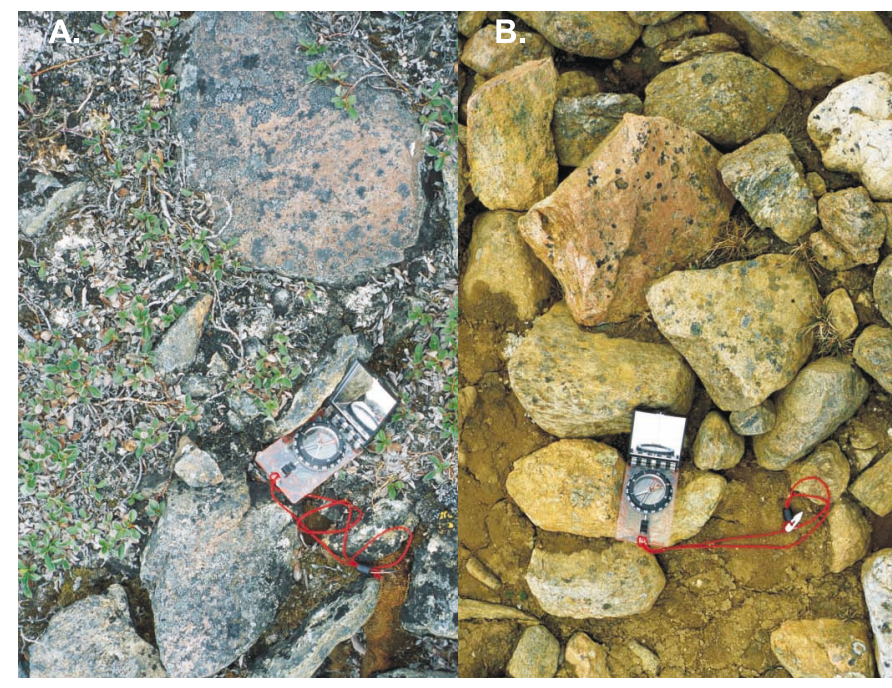

FIG. 3. Johan Peninsula, Ellesmere Island. Siliceous Precambrian substrate with (A) mature plant and lichen communities distal to the LIA trimline, and (B) a plant- and lichen-free area within the expansion zone. Bedrock in both A and B is Precambrian Shield.

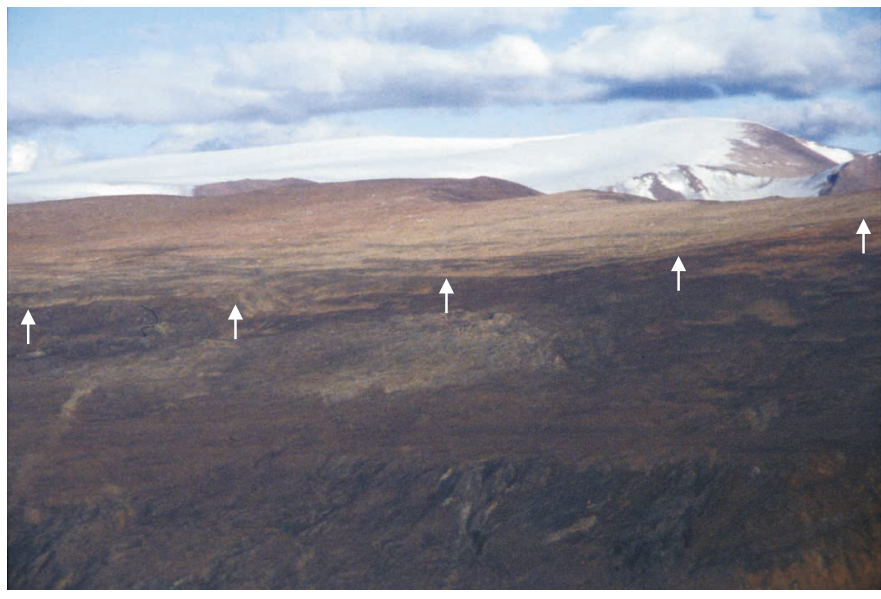

FIG. 4. Thorvald Peninsula, eastern Ellesmere Island. Recently exposed terrain with a diffuse boundary (white arrows) separating "lichen-free" areas from areas with mature lichen, bryophyte, and vascular plant communities that remained free of perennial snow and ice during the Little Ice Age.

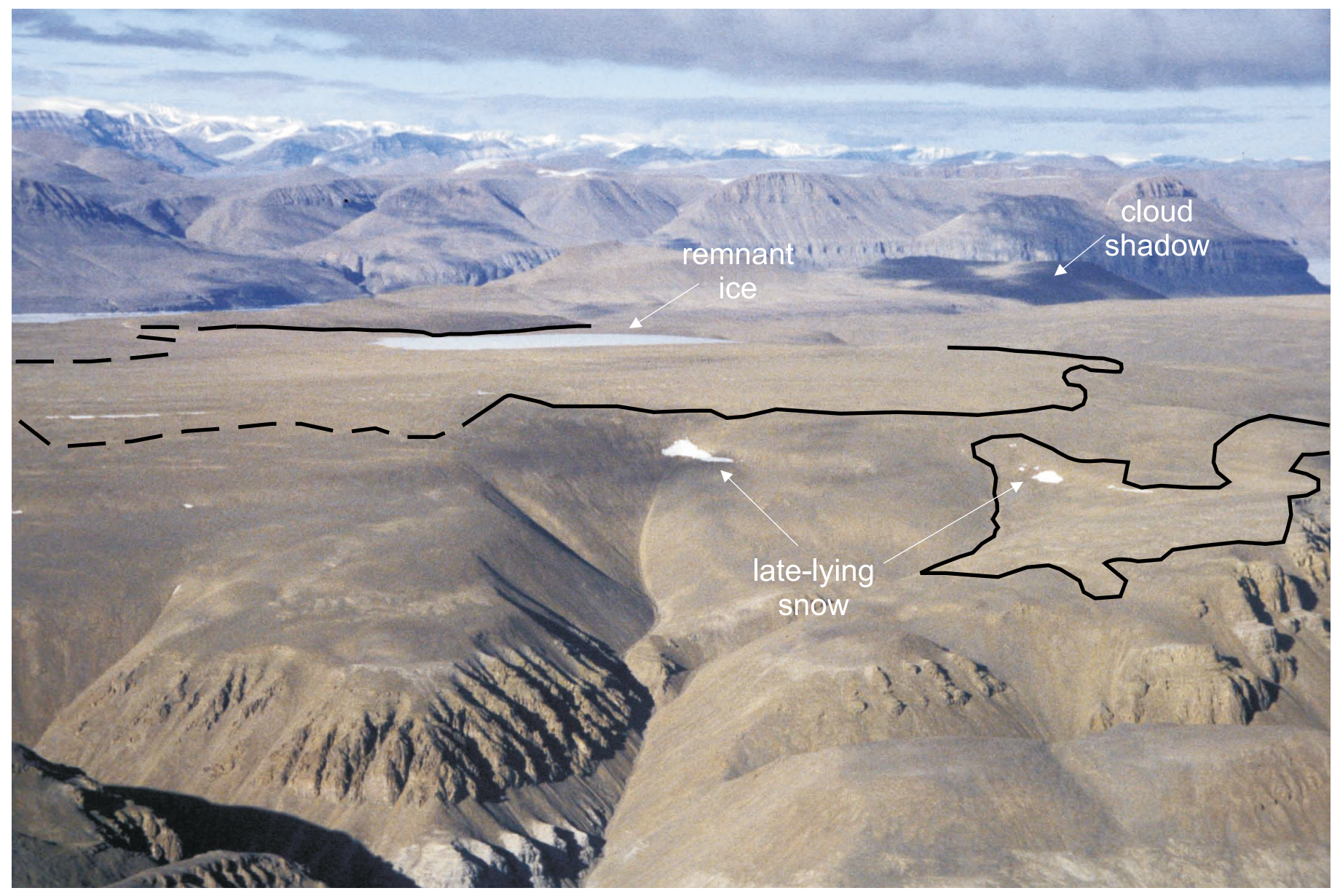

FIG. 5. Knud Peninsula, eastern Ellesmere Island. Trimlines and recently exposed terrain on a carbonate substrate surrounding a small plateau ice cap. Solid lines show abrupt trimlines, and dashed lines indicate diffuse trimlines (areas of transition from more weathered to less weathered terrain). Distal to the abrupt trimline, a conspicuous break in slope is visible, whereas the diffuse trimline is found on gently sloping terrain.

based on ${ }^{14} \mathrm{C}$ and lichenometric dates, the latter based on the diameter of the widespread crustose species Rhizocarpon geographicum. From these observations,
Andrews et al. (1976) concluded that the lowering of the regional snowline during the LIA ranged from 100 to $400 \mathrm{~m}$ below its modern elevation ( $\sim 900 \mathrm{~m}$ asl, Miller et al., 
1975). Locke and Locke (1977) also used air photos and Landsat-1 satellite imagery of north-central Baffin Island to map lichen-free areas. They reported that during the LIA, ice cover was $\sim 35 \%$ greater than the modern ice cover within their study area (i.e., $\sim 35890 \mathrm{~km}^{2}$ vs. $\sim 12600 \mathrm{~km}^{2}$ ) and was accompanied by a lowering of the glaciation level (GL) and equilibrium line altitude (ELA - a line representing the boundary between snow accumulation and snow ablation that delimits the elevation of perennial snow and ice) by as much as $400 \mathrm{~m}$.

Subsequent research has reported similar lichen-free zones from other islands of the Canadian Arctic Archipelago (Fig. 1). To the west of Baffin Island, Dyke (1978:215) described lichen-free areas close to $400 \mathrm{~m}$ asl on parts of NW Somerset Island, which "does not support late-lasting snowbanks today." Dyke suggested that the presence of greater snow and ice in the recent past (unspecified) precluded recolonization of this area. He also reported that other parts of the island that are underlain by calcareous rocks have ice retreat landforms of Neoglacial age, such as lateral meltwater channels and small eskerlike ridges. In the western Arctic, Edlund (1985) identified several areas of possible Neoglacial snow and ice expansion on Melville Island from vegetation trimlines in areas that had been snow-free for several weeks during the summer. Hodgson (1992) portrayed these areas with the same interpretation on his surficial geology map of western Melville Island, and Bednarski (2002) mapped similar features on Bathurst Island.

After Koerner's (1980) paper, nearly 15 years elapsed before an interest in lichen-free areas in Arctic Canada was renewed. The interpretations of barely vegetated upland terrain on Ellesmere Island advanced by botanists Levesque and Svoboda (1999) are fully compatible with Ives' (1962) hypothesis.

\section{DISCUSSION}

Koerner (1980) challenged the interpretation of socalled 'lichen-free' areas, claiming that inconsistencies in Ives' (1962) original hypothesis made it fundamentally incorrect. His five basic objections to Ives' theory concerned: (1) lichen survival under perennial snow/ice; (2) the method of lichen removal to develop trimlines; (3) the form of the trimlines; (4) the time interval, based on ${ }^{14} \mathrm{C}$ dates, assigned to the snow and ice cover expansion; and (5) the apparent "degree" of lichen-kill reported in the literature. Koerner proposed instead that the lichen-free areas had resulted from insufficient growing caused by late-lying snowbanks.

\section{Vegetation Trimlines and Lichen Physiology}

Vegetation trimline formation is largely a function of the physiological requirements for lichen growth and survival. Lichen survival in extreme environments is credited to their poikilohydric lifestyle (Green et al., 1999), that is, their ability to become dormant for long periods and reactivate rapidly. Dormancy results from the ability of lichens to undergo desiccation, whereby a thickening of the upper cortex prohibits photosynthesis and protects the lichen from temperature extremes and intense light (Raven et al., 1992). Reactivation is a result of rapid imbibition, which allows the upper cortex to thin and become translucent, thereby permitting photosynthesis to resume.

Lichen survival under snow or ice is largely a function of exposure to subnival moisture. In both the Arctic and the Antarctic, lichen communities are often found alive under seasonally persistent snowbanks, which occupy the same location year after year (Schroeter et al., 1994; Kappen et al., 1998; Green et al., 1999; Pannewitz et al., 2003). Pannewitz et al. (2003:37), describing lichen activity under snow in continental Antarctica, state that "lichens exposed for the first time late in the season will have almost the same productivity as those exposed earlier and there is little disadvantage to extended burial in snow as long as melting does eventually, and consistently, occur each season." They maintain that the similar productivity of late-exposed and early-exposed lichens is primarily due to similar photosynthetic activity periods, initiated by hydration from the melting snow edge and terminated (through desiccation) upon snow removal. However, lichen mortality occurs when a multi-year snow cover more than $\sim 30 \mathrm{~cm}$ thick prohibits photosynthetic activity of lichens that are hydrated (Körner, 1999; Pomeroy and Brun, 2001). Continued respiration of hydrated lichen thalli in the absence of photosynthesis diminishes carbon availability (Gannutz, 1970; Benedict, 1990; Kappen et al., 1995). If carbon reserves are not replenished, the fungal member of the lichen will parasitize the algal partner, ultimately causing the lichen to expire (Gannutz, 1970).

\section{Responding to Koerner's Objections}

Objection 1: The Survival of Lichen under Perennial Snow/Ice. Koerner's first objection concerns the manner of lichen kill. He cited observations by Beschel (1961) who claimed that lichens could survive in a state of dormancy under the protective cover of perennial snow or ice if basal meltwater was absent. Koerner (1980:88) expanded on this concept, stating that "...if the formation of permanent snowfields in the LIA was rapid, no melt may have penetrated to the basal layers of the permanent snowfields and there would be lichen survival rather than lichen-kill." Consequently, in Koerner's view lichens should have been able to reactivate and resume photosynthesis without delay following re-exposure after the termination of the LIA (Lang, 1972, cited by Koerner, 1980). Although the time for which lichens can endure this dormancy is not stated and may be unknown, it seems unlikely that it is without limits (e.g., Twin Glacier below).

Perennial snow-and-ice cover is inimical to the continuance of lichen and plant growth once the organisms are 


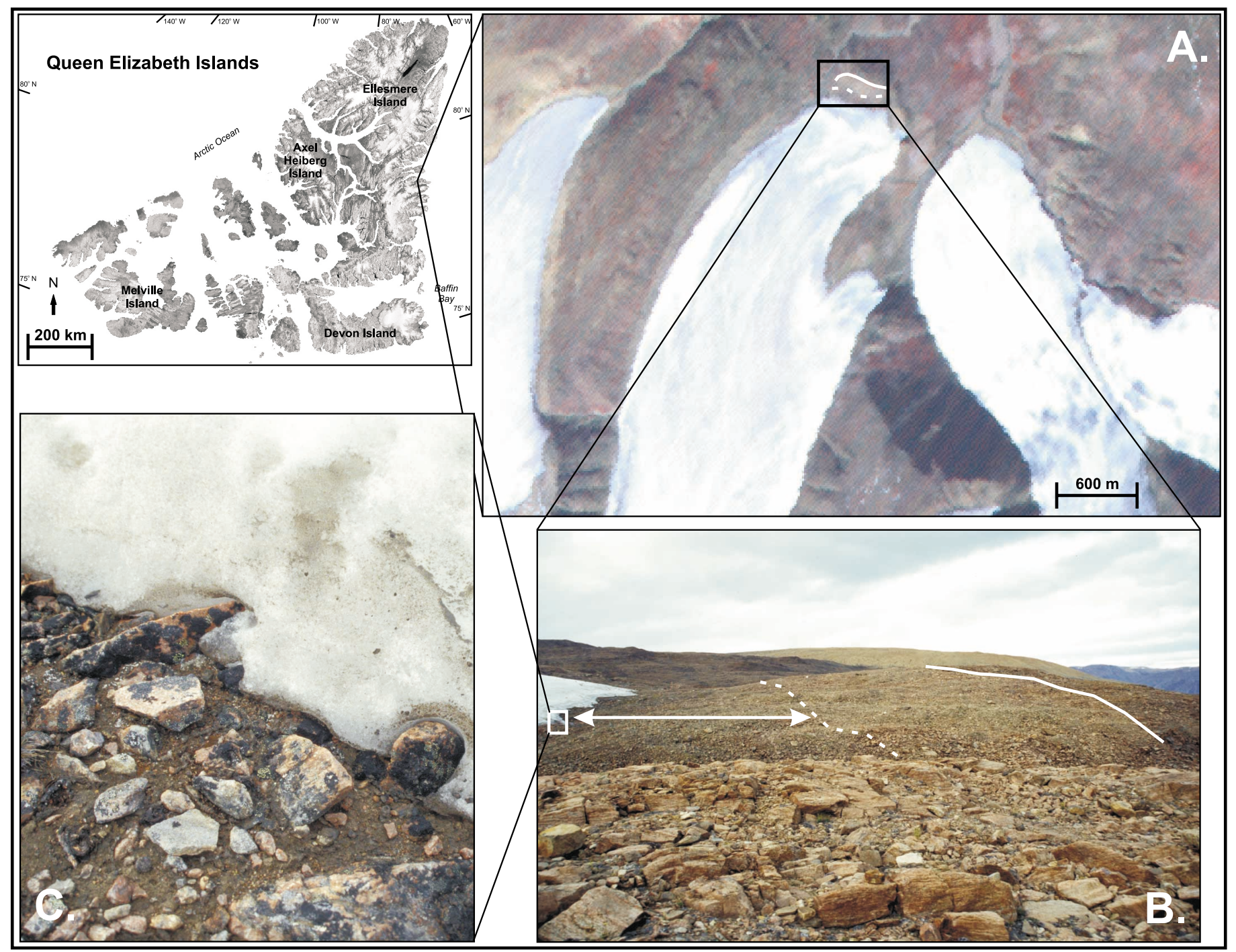

FIG. 6. Twin Glacier, Alexandra Fiord, Ellesmere Island. (A) ASTER image (SC:AST_L1A.003:2007830294) showing preserved dead lichen, bryophytes, and vascular plant communities as a dark band bordering the terminus of West Twin Glacier (between white dashed line and ice margin). Beyond the dashed line, the solid line indicates the abrupt trimline marking the former (LIA) ice margin. (B) Ground view showing the abrupt trimline (solid line, as in A) and outer margin of gradational dark zone (dashed line in A, and arrow) marking exhumed dead lichens, bryophytes, and vascular plants that have just been exposed by ongoing ice retreat $(\mathrm{C})$.

buried, and their death can likely result from the duration of that burial or the subnival environment. Recession of cold-based ice margins occasionally exhumes intact but dead lichen and plant communities. For example, Bergsma et al. (1984) reported that well-preserved but dead plants were exposed by the retreat of Twin Glacier in Alexandra Fiord, E. Ellesmere Island. Twin Glacier, like many High Arctic glaciers, is cold-based at its terminus; therefore, the preservation of ice-entombed dead vegetation and lichen communities results from the overall absence of subglacial meltwater and limited subglacial erosion. The preserved dead lichen and plant communities can be seen with highresolution, multispectral satellite imagery as a dark band bordering the terminus of Twin Glacier (Fig. 6). In southwest Yukon, Farnell et al. (2004) reported dark, lichencovered rock exposed at the retreating edge of alpine ice patches. These dark bands are surrounded by a "halo" of lichen-free terrain, the outer limit of which was thought to represent the LIA maximum ice patch extent (Farnell et al., 2004:251). As these ice masses retreat, renewed exposure to weathering and erosion expedites the disintegration and removal of dead vascular plants, mosses, and fruticose lichens first, followed by the more persistent crustose epipetric lichen species, which remain exposed for about 5-10 years prior to their removal (G. Henry, pers. comm. 2003). This duration is consistent with Benedict's (1990) observations in alpine regions of the Colorado Rocky Mountains, where he reported the complete removal of Rhizocarpon thalli by erosive agents one to three years after their death, although some dead lichens persisted for up to six years. Similar sequences of ice burial and subsequent exposure and removal of lichen and plant communities could also have applied to the former LIA snowfields and icecaps postulated by Ives and followers. 
Regardless of the duration of dormancy, however, lichen populations could have been destroyed during the initiation phase of the LIA event alone. If the onset of this cool interval was not constant, but rather was characterized by greater variability (Lamoureux, 2000; Lamoureux et al., 2001, 2002), there would have been ample opportunity for basal wetting to occur, causing lichen thalli to become hydrated beneath newly established LIA névés. As cooler intervals yielded to intervening warmer ones, the perennial snowfields would have been subject to melting, providing more than enough opportunity for meltwater to percolate to their base. Therefore, during these intra-Neoglacial warm periods, lichen populations within the trimline boundary would have been damaged (if not killed) by subnival meltwater, especially since underlying permafrost would have extended close to the surface, ensuring a perched water table (i.e., super-saturation).

Objection 2: The Method of Lichen Removal. Koerner's second objection was based primarily on the absence of bands of dead lichens (like those seen at Twin Glacier by Bergsma et al., 1984, and in southwest Yukon by Farnell et al., 2004) and his skepticism about a mechanism for their removal. He states that "on none of the aerial photographs that I have examined of the plateau northwest of the Devon Ice Cap is there any sign of a band of dead lichens (dark tone) flanking the retreating ice caps," and that "expansion of the permanent snow and ice cover during the Little Ice Age must have been over ground with an already sparse lichen cover" (Koerner, 1980:89). There are several evident retorts to these comments. First, apart from some Precambrian outcrops of Canadian Shield (where lichen communities characteristically thrive), the area northwest of the Devon Ice Cap is principally composed of carbonate rocks. Over this inhospitable substrate, the cover of lichen and plants on this terrain is already sparse; consequently, there would not be conspicuous bands of dead lichens surrounding retreating ice masses on this terrain. Second, as stated above, there would have been numerous opportunities to kill (by basal wetting) and remove (by erosion after exposure) lichen and plant communities during intra-Neoglacial warm periods before or during the LIA, regardless of lichen and plant cover or substrate type. Therefore, the terrain that was covered during the LIA expansion would have been sparsely populated with lichens because of previous kill and removal events. Third, if most dead lichens were removed during intra-Neoglacial warm periods, the only locations where one might have seen a dark band of dead lichens flanking a retreating ice cap would have been at the former limit of the largest expansion (advance), assuming that the greatest expansion occurred during the LIA. Moreover, the dark band of dead lichens would have been visible for only about 3-10 years (see above) following the peak of the LIA in the Canadian Arctic, roughly 160 years ago (Overpeck et al., 1997). Fourth, the localities where most perennial snow and ice expansions occurred are classified as polar deserts; recolonization would have been thwarted by the brevity of intra-Neoglacial warm periods, as this process today makes little progress within a century (Levesque and Svoboda, 1999). Finally, Koerner's objections regarding the manner of lichen kill, the mechanism of lichen removal, and the subsequent formation of trimlines simply do not apply to the non-vegetative trimlines that occur on carbonate terrain.

Objection 3: The Form of the Trimlines. Koerner's third objection referred to the abruptness of the trimline. $\mathrm{He}$ argued that "a diffuse boundary between lichen-free and lichen-covered areas should have developed rather than a trimline. This is because permanent snow and ice fields expand and contract areally in response to the varying intensity of melting from summer to summer. A permanent snowfield 1 to $2 \mathrm{~m}$ thick would disappear every few years after a particularly warm summer to reform a year or so later" (Koerner, 1980:90). First, the use of the descriptive terms "abrupt" and "diffuse" depends entirely on the scale at which the mapping is being conducted. A gradational transition of several meters on the ground might appear abrupt to analysts using remote sensing imagery (satellite or aerial images) - especially to early investigators (Andrews et al., 1976; Locke and Locke, 1977) using Landsat 1 imagery, which has a ground resolution of $80 \mathrm{~m}$. Second, according to Ives' (1962) hypothesis, the trimlines represent the outer margins of perennial snow and ice expansions that were of sufficient duration to kill the affected plant and lichen cover. The hypothesis does not exclude intervals of greater snow cover that were too brief to kill the plant cover, nor does it specify an unvarying snowfield configuration throughout the LIA. Compositionally, the margin of this expansion must have been firn or superimposed ice. The abruptness of most trimlines indicates that the firn (or ice) was sufficiently thick to withstand variations in the annual melt rate long enough to kill the plant cover to that limit. The annual snowline, however, could have occupied positions below or above the elevation of the firn/ice margin in any particular year, just as it does today on glaciers and icecaps (Fig. 7). Therefore, the firn (or ice) margin that produced the welldefined trimline was the integrated (multi-year) ELA, developed in response to snowline oscillations that occurred over several, perhaps many, years.

Although most trimlines are abrupt, Ives' hypothesis does not exclude the possibility of diffuse trimlines. In fact, diffuse boundaries rather than abrupt trimlines did form in many areas (Figs. 4 and 8). Diffuse trimlines simply reflect perennial snowfields whose margins were more vulnerable to movement caused by variations in melt intensity. These diffuse trimlines are typically found on low-angle slopes of fiord uplands or plateaus, where a small change in the altitude of the annual snowline would cause a larger area to be incorporated into either the accumulation area or the ablation area. Abrupt trimlines are generally found in broad meltwater channels, on hilly terrain, and on uneven terrain (Fig. 8). Modern accumulation in broad meltwater channels and on hilly terrain 

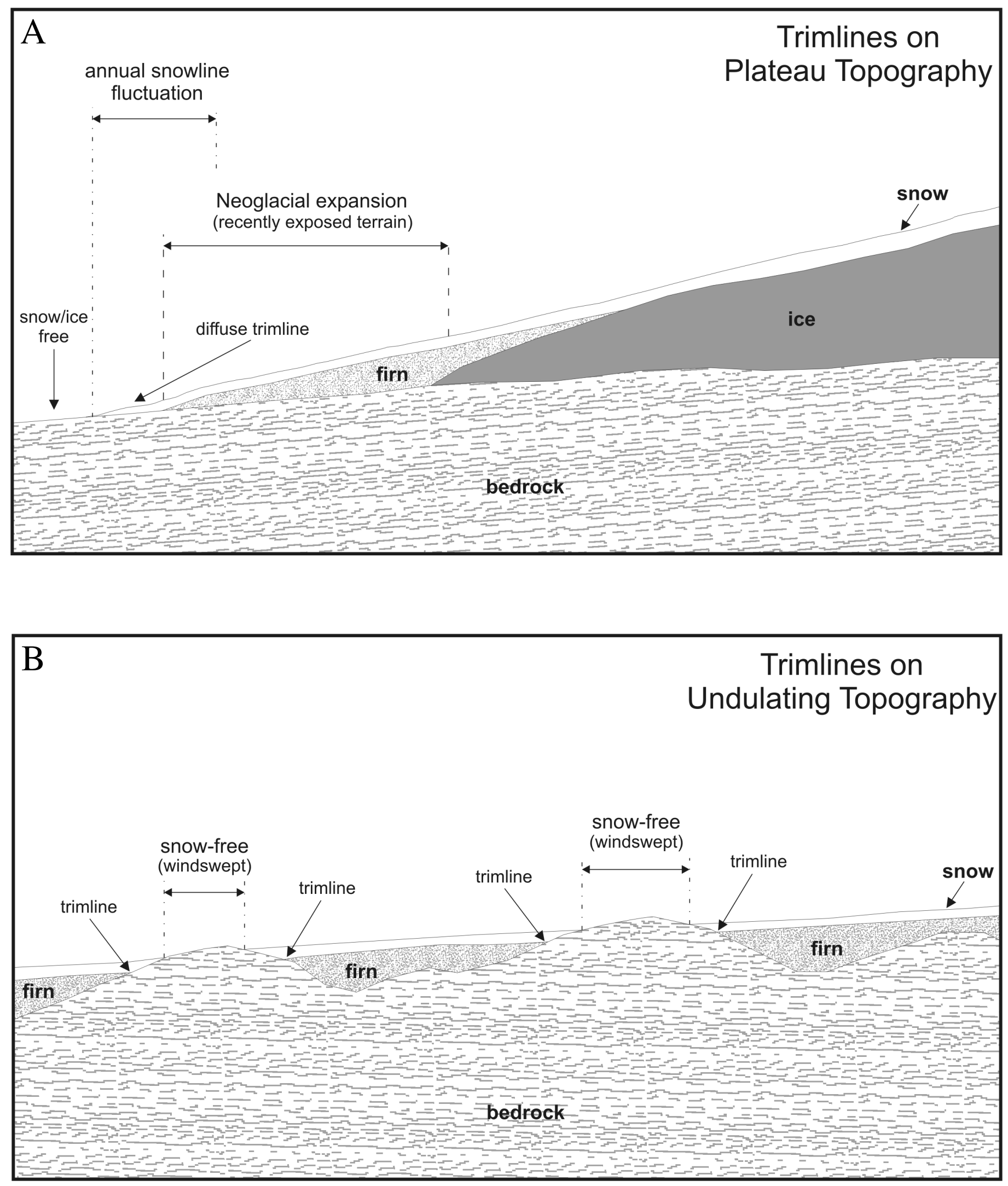

FIG. 7. Cross-section model of trimline formation. (A) Diffuse trimline formed as a result of long-term snowline lowering on gently sloping terrain typical of plateau topography. After the snow has survived one melt season, it is transformed into firn. The annual snowline fluctuates, intermittently exposing the firn/ice layer to melt, which results in the formation of a diffuse trimline. (B) Trimlines formed on undulating terrain where the tops of the hillocks are deflated and the depressions are filled with drifted snow, which is eventually transformed into firn/ice. This process creates a discontinuous trimline configuration and gives a mottled appearance to the landscape. 


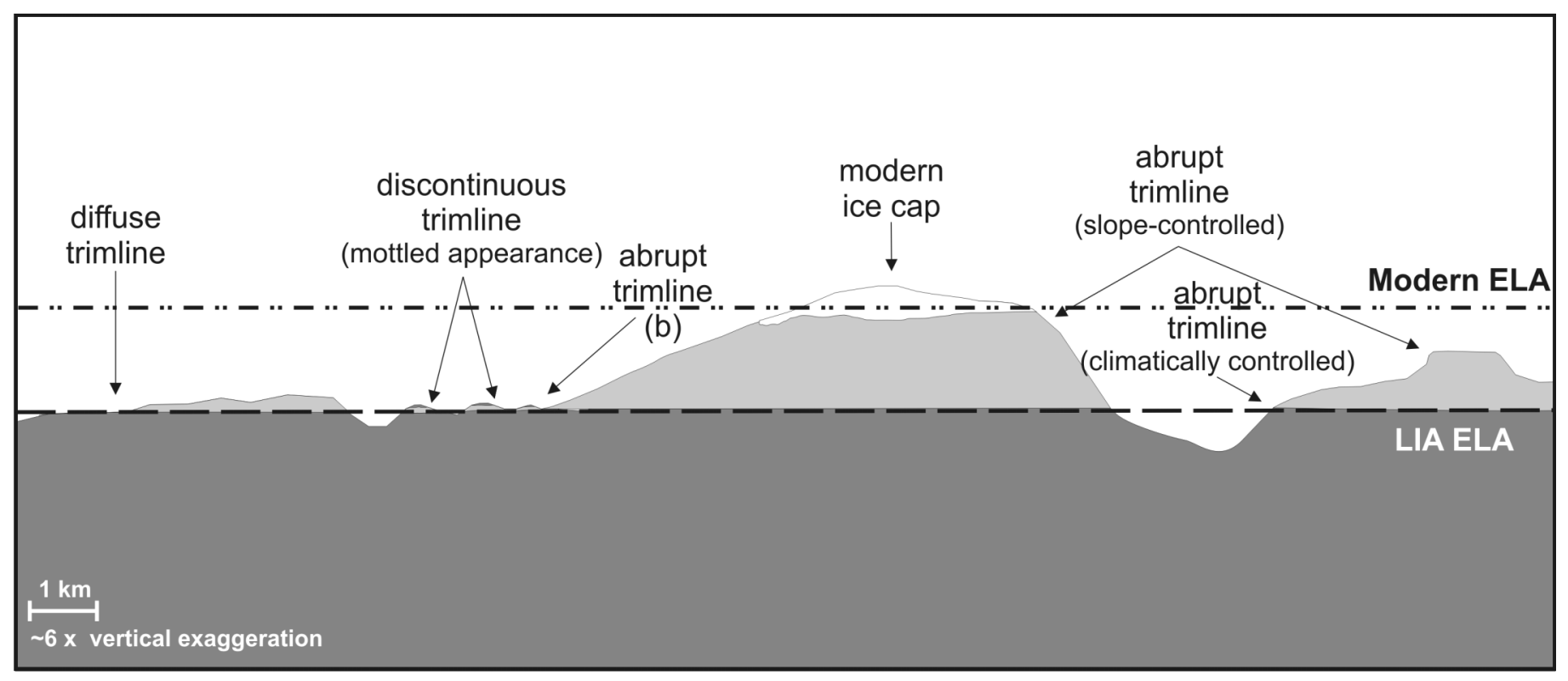

FIG. 8. Cross-section model of a High Arctic landscape, showing modern ELA vs. LIA ELA. Lighter-toned land above the LIA ELA indicates those areas that were largely covered by perennial snow and ice (i.e., within the accumulation area). Trimline forms are discontinuous, diffuse, abrupt climatically controlled, and abrupt slope-controlled. Abrupt slope-controlled trimlines form where the terrain becomes too steep for snow to accumulate. Since these occur above the ELA, they are not considered climatically significant.

generally reflects the prevailing wind direction (i.e., accumulation on the lee side of hills or former channel banks); therefore, trimlines associated with these features should reflect the prevailing wind direction during the time of trimline formation. On uneven or undulating terrain, the process of wind drifting favors accumulation in depressions and deflation from ridges capable of sustaining lichen cover (Figs. 7 and 9). Koerner correctly identified this pattern, but he insisted that it was linked to seasonally persistent snowfields, and that "an exclusively climatic control would surely produce the reverse effect of permanent snowfields (i.e., lichen-free zones) on higher ground" (Koerner, 1980:92). In the simplest sense, we agree; examples of lichen-free zones on higher ground caused by this "exclusively climatic control" can be seen on numerous plateaus throughout the Canadian High Arctic (Fig. 9). On more topographically complex terrain, the climatic effect is more complicated, but it is still a "climatic control," much the same as those controls that affect levels of glaciation in a region. Furthermore, if these topographically low areas are prone to frequent accumulation today, surely this condition would have been common during the LIA, or other cold intervals throughout the Neoglacial, because snowmelt would have been limited.

Objection 4: The Time of Lichen-Kill. Koerner's fourth objection was in regard to the time of lichen-kill, i.e., the age of the perennial snow and ice expansion. He argued that "the evidence [based on a few ${ }^{14} \mathrm{C}$ dates] for a Little Ice Age permanent snowfield expansion and lichenkill is not very compelling...only two dates are attributable to the Little Ice Age and these are on material collected close to present day ice masses" (Koerner, 1980:90). This argument is correct: there were then and are now too few suitable ${ }^{14} \mathrm{C}$ dates for the event. The relevance of the existing age determinations is that they place the lichen and plant-kill event in the latest Holocene, which is all that can be expected of the method, given the non-linear atmospheric carbon production for this time interval (Stuiver, 1978). Refining the temporal constraints on this event is fundamental, and new methods for obtaining these must be explored.

Objection 5: The "Degree" of Lichen-Kill. Koerner based his final objection on the use of the terms "heavy" and "moderate" as applied by Andrews et al. (1976:76) in their descriptions of the extent of lichen-kill for large areas: "Compounding the problem is the fact that there is a degree of lichen-kill.... It is difficult to see how some permanent snowfields are more lethal than others" (Koerner, 1980:89). This is an argument of semantics. Although the terms were not explicitly defined, Andrews et al. (1976) used "heavy" lichen-kill to describe vast areas devoid of mature lichen and plant covers and "moderate" to portray areas with discontinuous (mottled) or diffuse patterns of lichen-kill. They also use the word "heavy" to portray a densely populated or mature lichen cover; hence, in both cases, "heavy" becomes synonymous with "clearly defined."

\section{Revisiting Koerner's Hypothesis for the Origin of Trimlines}

Koerner's objections to Ives' (1962) hypothesis do not lead us to reject the use of trimlines as a tool for paleoclimatic reconstruction. Furthermore, there appears to be a fundamental gap in Koerner's alternative ecological hypothesis for the formation of lichen-free zones, particularly in instances where sharp trimlines are observed. In 


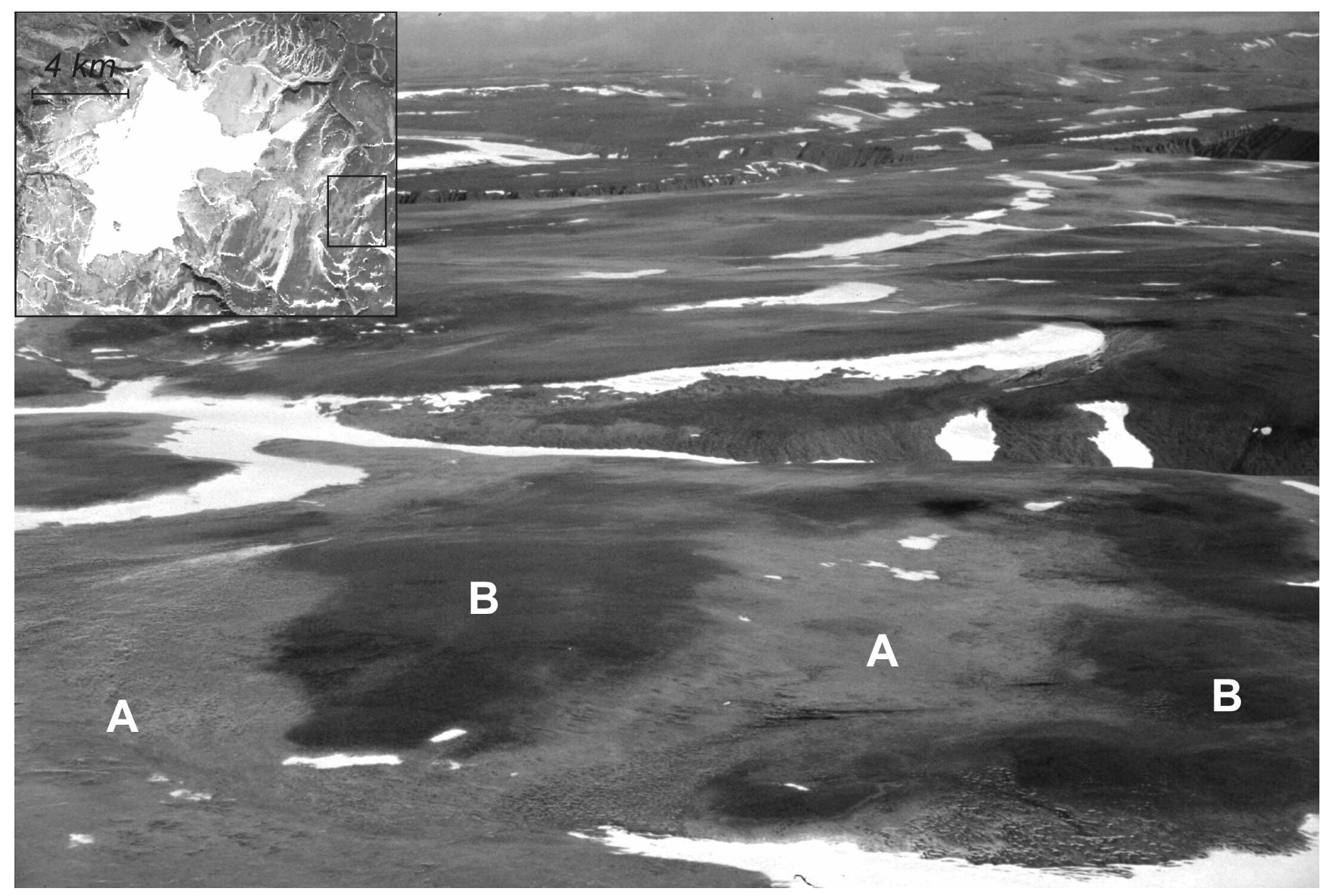

FIG. 9. Distal (lowest) region of a former plateau ice cap expansion area showing (A) lichen-free areas that resulted from accumulation and preservation of snow and ice in depressions, and (B) lichen-covered higher areas where snow was removed by deflation (see Fig. 7b for related schematic diagram). Inset is a Landsat 7 ETM+ (2001) subset of the Blue Hills region and the south ice cap of western Melville Island. The dark rectangle on the inset image shows the approximate area captured by the photograph.

Koerner's hypothesis, "lichen-free zones are coincident with snow covers that persist through a large part of, but not all, the melt season. These snow covers inhibit lichen growth by drastically reducing their growing season" (Koerner, 1980:91). According to this hypothesis, two possible mechanisms could explain sharp trimlines. The first possibility is that a sharp trimline must be formed by a pause (for some critical length of time) of the annually retreating snow edge, followed by continued retreat. The location where the snow edge consistently pauses every year would then divide the terrain into biologically viable and biologically non-viable areas. The second possibility is that the annual retreat of the snow edge must progress at the same rate every year, thereby reaching the critical threshold in the growing season length at the same location on the landscape year after year. These mechanisms are not feasible, given the interannual variability in snowline position in the Canadian Arctic. We found no consistently late-lasting snow cover in areas where trimlines have been documented. Moreover, even if consistent late-lasting snow cover had been observed, there seems to be no disadvantage to lichens that are uncovered later in the season compared to those that are uncovered earlier in polar desert environments (see Vegetation Trimlines and Lichen Physiology above; Pannewitz et al., 2003).

\section{Using LIA Trimlines for Equilibrium-Line Altitude Reconstruction}

How can trimlines be used to reconstruct past climatic conditions? In order to answer this question, it is necessary to consider the type of perennial ice mass that was responsible for the creation of the trimlines, and whether the trimlines record a synchronous ice advance and retreat across a given region, such as the QEI.

In the High Arctic, numerous plateaus are at or just below the modern ELA (England et al., 1981). Today, trimlines are widespread on these plateaus and can be found around thin, stagnant, cold-based ice caps (Fig. 5), as well as on fiord uplands and plateaus where ice has entirely disappeared (Fig. 4). These trimlines are analogous to those originally identified by Ives (1962) on Baffin Island. Here they are attributed to long-term snowline lowering below a former ice margin, forming snow aprons, rather than to expansion by active internal flow. If snowapron expansion produced these trimlines, then they record 
the former ELA, which provides an important proxy for climatic reconstruction. This interpretation is strengthened when ice-cap trimlines are accordant with nearby trimlines linked to former perennial snowfields. In these cases, the trimlines must be the product of snowline lowering (rather than ice flow) beyond the former margin, and they can be used as a record of the ELA during the LIA. Where ice-cap trimlines extend to lower elevations than neighboring trimlines produced by perennial snowfields, this disparity must be due to flow carrying ice into the ablation zone, precluding the use of these flow-produced trimlines as a record of the former ELA. Trimlines associated with former perennial snowbanks that were influenced by topography can also record exceptionally low ELAs that are less precise indicators of regional climate. While these features do provide some information about former environmental conditions, their survival is often the product of other factors, such as wind drifting and aspect.

\section{CONCLUSIONS}

Trimlines associated with former snow and ice expansions in the Canadian Arctic can be used for paleoenvironmental reconstruction. Their interpretation involves both glaciological and biological considerations, especially concerning lichenological research relevant to their origin. One of the key arguments that trimlines do record former ELAs comes from widespread areas where the lower limit of former perennial snowfields or ice patches, as defined by trimlines, are accordant with trimlines left by small plateau ice caps. However, the timing of the event that produced the trimlines is still uncertain; applying new dating techniques to this facet of the Arctic landscape is essential to refining the timing of its formation.

Revalidating the use of LIA trimlines is important for several reasons. First, mapping LIA trimlines may offer further insight into past glaciations by using the Neoglacial ice cover as an example of Arctic ice nucleation, serving as a possible precursor to the build-up of the Innuitian Ice Sheet that occupied the QEI during the last glaciation (i.e., late Wisconsinan, Blake, 1970, 1972, 1992; Bednarski, 1998; Dyke, 1999; England, 1999; Dyke et al., 2002). Second, trimlines can be used to provide a measure of the amount of snow and ice present near the onset of the 20th century, and hence, as a measure of subsequent reduction. Third, relative to modern climatic conditions, the reconstructed ELAs can be used to help estimate temperature and precipitation changes between the LIA and the present. Finally, mapping LIA trimlines can provide a valuable data set of snow and ice extent and attendant climatic conditions to test coupled ice sheet-climate models simulating the LIA. Successfully modeling the LIA will improve our ability to assess the impacts of predicted future climate change on Arctic glaciers and sea level.

\section{ACKNOWLEDGEMENTS}

Financial support for this research was provided by the Natural Sciences and Engineering Research Council of Canada (NSERC Discovery Grant A6680) and the NSERC Northern Chair Award, both to J. England. Additional support to G. Wolken was provided by the Canadian Circumpolar Institute (University of Alberta, Edmonton, Alberta). The Polar Continental Shelf Project, Natural Resources Canada, provided logistical support for this project during the summers of 2002 and 2003 on Melville and Ellesmere islands. We are grateful to M. Sharp for providing Landsat 7 ETM+ imagery, purchased through support from CRYSYS (Cryospheric System to Monitor Global Change in Canada). ASTER (Advanced Spaceborne Thermal Emission and Reflection Radiometer) imagery was provided by the GLIMS (Global Land Ice Measurements from Space) project. The National Hydrology Research Institute, Environment Canada, provided aerial photography. We wish to recognize comments by L. Dredge and D. Hodgson (GSC, Ottawa) on an earlier draft of the manuscript. We also wish to acknowledge internal reviews by R.M. Koerner (GSC, Ottawa) and J. Bednarski (GSC, Calgary) on behalf of the Terrain Sciences Division. Finally, we thank the four anonymous reviewers for their comments, which helped to clarify the manuscript.

\section{REFERENCES}

ANDREWS, J.T., and WEBBER, P. 1964. A lichenometrical study of the northwestern margin of the Barnes Ice Cap; a geomorphological technique. Geography Bulletin 22:80-104. Ottawa: Canada Department of Mines and Technical Surveys.

ANDREWS, J.T., BARRY, R.G., DAVIS, P.T., DYKE, A.S., MAHAFFY, M., WILLIAMS, L.D., and WRIGHT, C. 1975. The Laurentide Ice Sheet: Problems of the mode and speed of inception. World Meteorological Publication 421:87-94.

ANDREWS, J.T., DAVIS, P.T., and WRIGHT, C. 1976. Little Ice Age permanent snowcover in the eastern Canadian Arctic: Extent mapped from Landsat-1 satellite imagery. Geografiska Annaler 58A:71-81.

BARRY, R.G., ANDREWS, J.T., and MAHAFFY, M.A. 1975. Continental ice sheets: Conditions for growth. Science 190: 979-981.

BEDNARSKI, J.H. 1998. Quaternary history of Axel Heiberg Island bordering Nansen Sound, Northwest Territories, emphasising the last glacial maximum. Canadian Journal of Earth Sciences 35:520-533.

. 2002. Surficial geology, northeast Bathurst Island, Nunavut. Geological Survey of Canada, Map 2011A, scale 1:100 000.

BENEDICT, J.B. 1990. Lichen mortality due to late-lying snow Results of a transplant study. Arctic and Alpine Research 22: $81-89$.

BENN, D.I., and EVANS, D.J.A. 1998. Glaciers and glaciation. London: Oxford University Press.

BERGSMA, B.M., SVOBODA, J., and FREEDMAN, B. 1984. Entombed plant communities released by a retreating glacier at Central Ellesmere Island, Canada. Arctic 37(1):49-52. 
BESCHEL, R. 1961. Dating rock surfaces by lichen growth and its application to glaciation and physiography (lichenometry). Geology of the Arctic:1044-1062.

BLAKE, W., Jr. 1970. Studies of the glacial history in Arctic Canada I: Pumice, radiocarbon dates and differential postglacial uplift in the eastern Queen Elizabeth Islands. Canadian Journal of Earth Sciences 7:634-664.

1972. Climatic implications of radiocarbon-dated driftwood in the Queen Elizabeth Islands, Arctic Canada. In: Vasari, Y., Hyvarinen, H., and Hicks, S., eds. Climatic change in the Arctic areas during the last ten thousand years. Oulu, Finland: University of Oulu. $77-104$.

- 1992. Holocene emergence at Cape Herschel, east-central Ellesmere Island, Arctic Canada - Implications for ice-sheet configuration. Canadian Journal of Earth Sciences 29: 1958-1980.

BRADLEY, R.S. 1990. Holocene paleoclimatology of the Queen Elizabeth Islands, Canadian High Arctic. Quaternary Science Reviews 9:365-384.

DREDGE, L.A. 2004a. Surficial geology, Ekalugad Fiord (West half), Baffin Island, Nunavut. Geological Survey of Canada, Map 2073A, scale 1:250000.

—. 2004b. Surficial geology, Lake Gillian, Baffin Island, Nunavut. Geological Survey of Canada, Map 2076A, scale $1: 250000$.

- 2004c. Surficial geology, McBeth Fiord (West half), Baffin Island, Nunavut. Geological Survey of Canada, Map 2074A, scale 1:250000.

DYKE, A.S. 1978. Indications of neoglacierization on Somerset Island, District of Franklin. Scientific and Technical Notes, Current Research, Part B. Ottawa: Geological Survey of Canada. 215-217.

DYKE, A.S. 1999. Last glacial maximum and deglaciation of Devon Island, Arctic Canada: Support for an Innuitian Ice Sheet. Quaternary Science Reviews 18:393-420.

- 2000a. Surficial geology, Arctic Bay, Baffin Island. Geological Survey of Canada, Map 1964A, scale 1:250 000.

- 2000b. Surficial geology, Milne Inlet, Baffin Island. Geological Survey of Canada, Map 1962A, scale 1:250000.

- 2000c. Surficial geology, Moffet Inlet and Fitzgerald Bay, Baffin Island. Geological Survey of Canada, Map 1963A, scale $1: 250000$

- 2000d. Surficial geology, Navy Board Inlet, Baffin Island. Geological Survey of Canada, Map 1965A, scale 1:250000.

- 2000e. Surficial geology, Phillips Creek, Baffin Island. Geological Survey of Canada, Map 1961A, scale 1:250000.

- 2001a. Surficial geology, Cardigan Strait, Devon Island and Ellesmere Island. Geological Survey of Canada, Map 1974A, scale 1:250 000 .

. 2001b. Surficial geology, central Devon Island. Geological Survey of Canada, Map 1971A, scale 1:250000.

-2001c. Surficial geology, eastern Devon Island. Geological Survey of Canada, Map 1970A, scale 1:250000.

- 2001d. Surficial geology, Grinnell Peninsula, Devon Island. Geological Survey of Canada, Map 1973A, scale 1:250000.

-2001e. Surficial geology, western Devon Island. Geological Survey of Canada, Map 1972A, scale 1:250000.
- 2003. Surficial geology, Erichsen Lake, Baffin Island, Nunavut. In: Geological Survey of Canada, Open File 4484. CD-ROM with digital files (geology, topography, and hydrology) of Open Files 1598-1613 (previously released as paper maps at 1:50 000 scale).

- 2004. Surficial geology, Erichsen Lake, Baffin Island, Nunavut. Geological Survey of Canada, Map 2066A, scale $1: 250000$.

DYKE, A.S., and HOOPER, J. 2000. Surficial geology, Berlinguet Inlet and Bourassa Bay, Baffin Island. Geological Survey of Canada, Map 1960A, scale 1:250 000.

DYKE, A.S., ANDREWS, J.T., CLARK, P.U., ENGLAND, J.H., MILLER, G.H., SHAW, J., and VEILLETTE, J.J. 2002. The Laurentide and Innuitian ice sheets during the Last Glacial Maximum. Quaternary Science Reviews 21:9-31.

EDLUND, S.A. 1985. Lichen-free zones as neoglacial indicators on western Melville Island, District of Franklin. Current Research, Part A, Geological Survey of Canada Paper 85-1A. 709-712.

ENGLAND, J. 1999. Coalescent Greenland and Innuitian ice during the Last Glacial Maximum: Revising the Quaternary of the Canadian High Arctic. Quaternary Science Reviews 18: 421-456.

ENGLAND, J., KERSHAW, L., LAFARGE-ENGLAND, C., and BEDNARSKI, J. 1981. Northern Ellesmere Island: A natural resources inventory. Edmonton: Department of Geography, University of Alberta.

FALCONER, G. 1966. Preservation of vegetation and patterned ground under a thin ice body in north Baffin Island, N.W.T. Canada. Geographical Bulletin 8:194-200.

FARNELL, R., HARE, P.G., BLAKE, E., BOWYER, V., SCHWEGER, C., GREER, S., and GOTTHARDT, R. 2004. Multidisciplinary investigations of alpine ice patches in southwest Yukon, Canada: Paleoenvironmental and paleobiological investigations. Arctic 57(3):247-259.

FLOHN, H. 1974. Background to a geophysical model of the initiation of the next glaciation. Quaternary Research 4: $385-404$.

GAJEWSKI, K., and ATKINSON, D.A. 2003. Climatic change in northern Canada. Environmental Reviews 11:69-102.

GANNUTZ, T.P. 1970. Photosynthesis and respiration of plants in the Antarctic Peninsula area. Antarctic Journal of the United States 5(2):49-51.

GREEN, T.G.A., SCHROETER, B., and SANCHO, L.G. 1999. Plant life in Antarctica. New York: Dekker.

GROVE, J.M. 1988. The Little Ice Age. London: Methuen.

HODGSON, D.A. 1992. Quaternary geology of western Melville Island, Northwest Territories. Geological Survey of Canada Paper 89-21:1-35.

HOOPER, J., and DYKE, A.S. 2000. Surficial geology, Agu Bay and Easter Cape, Baffin Island. Geological Survey of Canada, Map 1959A, scale 1:250000.

IVES, J.D. 1957. Glaciation of the Torngat Mountains, northern Labrador. Arctic 10(2):67-87.

. 1962. Indication of recent extensive glacierization in north central Baffin Island, N.W.T. Journal of Glaciology $4: 197-205$. 
IVES, J.D., ANDREWS, J.T., and BARRY, R.G. 1975. Growth and decay of the Laurentide Ice Sheet and comparisons with FennoScandinavia. Naturwissenschaften 62:118-125.

KAPPEN, L., SOMMERKORN, M., and SCHROETER, B. 1995. Carbon acquisition and water relations of lichens in polar regions - Potentials and limitations. Lichenologist 27:531 -545.

KAPPEN, L., SCHROETER, B., GREEN, T.G.A., and SEPPELT, R.D. 1998. Microclimatic conditions, meltwater moistening, and the distributional pattern of Buellia frigida on rock in a southern continental Antarctic habitat. Polar Biology 19: $101-106$.

KAUFMAN, D.S., AGER, T.A., ANDERSON, N.J., ANDERSON, P.M., ANDREWS, J.T., BARTLEIN, P.J., BRUBAKER, L.B., COATS, L.L., CWYNAR, L.C., DUVALL, M.L., DYKE, A.S., EDWARDS, M.E., EISNER, W.R., GAJEWSKI, K., GEIRSDOTTIR, A., HU, F.S., JENNINGS, A.E., KAPLAN, M.R., KERWIN, M.W., LOZHKIN, A.V., MACDONALD, G.M., MILLER, G.H., MOCK, C.J., OSWALD, W.W., OTTOBLIESNER, B.L., PORINCHU, D.F., RUHLAND, K., SMOL, J.P., STEIG, E.J., and WOLFE, B.B. 2004. Holocene thermal maximum in the western Arctic $\left(0-180^{\circ} \mathrm{W}\right)$. Quaternary Science Reviews 23:529-560.

KOERNER, R.M. 1980. The problem of lichen-free zones in Arctic Canada. Arctic and Alpine Research 12:87-94.

KOERNER, R.M., and FISHER, D.A. 1990. A record of Holocene summer climate from a Canadian high-Arctic ice core. Nature 343:630-631.

KÖRNER, C. 1999. Alpine plant life. New York: Springer.

LAMOUREUX, S. 2000. Five centuries of interannual sediment yield and rainfall-induced erosion in the Canadian High Arctic recorded in lacustrine varves. Water Resources Research 36: $309-318$.

LAMOUREUX, S.F., ENGLAND, J.H., SHARP, M.J., and BUSH, A.B.G. 2001. A varve record of increased 'Little Ice Age' rainfall associated with volcanic activity, Arctic Archipelago, Canada. The Holocene 11:243-249.

LAMOUREUX, S.F., GILBERT, R., and LEWIS, T. 2002. Lacustrine sedimentary environments in high Arctic proglacial
Bear Lake, Devon Island, Nunavut, Canada. Arctic, Antarctic, and Alpine Research 34:130-141.

LEVESQUE, E., and SVOBODA, J. 1999. Vegetation reestablishment in polar "lichen-kill" landscapes: A case study of the Little Ice Age impact. Polar Research 18:221-228.

LOCKE, C.W., and LOCKE, W.W. 1977. Little Ice Age snowcover extent and paleoglaciation thresholds: North-central Baffin Island, N.W.T., Canada. Arctic and Alpine Research 9: $291-300$.

MILLER, G.H., BRADLEY, R. S., and ANDREWS, J.T. 1975. The glaciation level and lowest equilibrium line altitude in the High Canadian Arctic: Maps and climatic interpretation. Arctic and Alpine Research 7:155-168.

OVERPECK, J., HUGHEN, K., HARDY, D., BRADLEY, R., CASE, R., DOUGLAS, M., FINNEY, B., GAJEWSKI, K., JACOBY, G., JENNINGS, A., LAMOUREUX, S., LASCA, A., MACDONALD, G., MOORE, J., RETELLE, M., SMITH, S., WOLFE, A., and ZIELINSKI, G. 1997. Arctic environmental change of the last four centuries. Science 278:1251-1256.

PANNEWITZ, S., SCHLENSOG, M., GREEN, T.G.A., SANCHO, L.G., and SCHROETER, B. 2003. Are lichens active under snow in continental Antarctica? Oecologia 135:30-38.

POMEROY, J., and BRUN, E. 2001. Physical properties of snow. In: Jones, H.G., Pomeroy, J., Walker, D.A., and Hoham, R., eds. Snow ecology: An interdisciplinary examination of snow-covered ecosystems. Cambridge: Cambridge University Press. 45-127.

RAVEN, P.H., EVERT, R.F., and EICHHORN, S.E. 1992. Biology of plants. New York: Worth.

SCHROETER, B., GREEN, T.G.A., KAPPEN, L., and SEPPELT, R.D. 1994. Carbon dioxide exchange at subzero temperatures. Field measurements on Umbilicaria aprina in Antarctica. Cryptogam Botany 4:233-241.

STUIVER, M. 1978. Radiocarbon timescale tested against magnetic and other dating methods. Nature 273(5660):271-274.

WILLIAMS, L.D. 1975. The variation of corrie elevation and equilibrium line altitude with aspect in eastern Baffin Island, N.W.T., Canada. Arctic and Alpine Research 7:169-181. 